\title{
Matthew Bardell, La Cort d'Amor. A Critical Edition
}

\section{G. Matteo Roccati}

\section{(2) OpenEdition}

\section{Journals}

\section{Édition électronique}

URL : https://journals.openedition.org/studifrancesi/38946

DOI : 10.4000/studifrancesi.38946

ISSN : 2427-5856

\section{Éditeur}

Rosenberg \& Sellier

\section{Édition imprimée}

Date de publication : 1 décembre 2004

Pagination : 333-334

ISSN : 0039-2944

\section{Référence électronique}

G. Matteo Roccati, « Matthew Bardell, La Cort d'Amor. A Critical Edition », Studi Francesi [En ligne], 143 (XLVIII | II) | 2004, mis en ligne le 30 novembre 2015, consulté le 19 mai 2021. URL : http://

journals.openedition.org/studifrancesi/38946 ; DOI : https://doi.org/10.4000/studifrancesi.38946

Ce document a été généré automatiquement le 19 mai 2021.

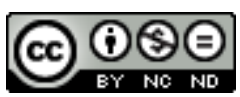

Studi Francesi è distribuita con Licenza Creative Commons Attribuzione - Non commerciale - Non opere derivate 4.0 Internazionale. 


\title{
Matthew Bardell, La Cort d'Amor. A Critical Edition
}

\author{
G. Matteo Roccati
}

\section{RÉFÉRENCE}

MATTHEW BARDELL, La Cort d'Amor. A Critical Edition, Oxford, Legenda, European

Humanities Research Centre, University of Oxford («Research Monographs in French Studies», 11), 2002, pp. X-170.

1 La Cort d'Amor est un texte allégorique occitan, écrit d'après l'éditeur à la fin du XIIe siècle pour la cour de Champagne. Incomplet (1721 octosyllabes), il est conservé dans un manuscrit unique: Chansonnier provençal N, Pierpont Morgan Library, M.819.

2 Dans l'introduction (pp. 1-39) l'éditeur passe en revue la bibliographie critique en s'arrêtant plus particulièrement sur les données relatives au manuscrit et à la datation du texte; il donne un résumé de ce dernier, en présente les caractéristiques et en montre l'intérêt: réponse en quelque sorte au De amore d'André le Chapelain, La Cort d'Amor offre, près de cinquante ans avant Guillaume de Lorris, un récit allégorique inspiré des traditions courtoise et ovidienne.

3 L'édition (avec l'indication des leçons rejetées en bas de page) est accompagnée de la traduction anglaise en regard. Elle est suivie des notes (pp. 136-157) et du glossaire (divisé en deux parties: formes occitanes, gallicismes). La bibliographie et l'index (des noms et des concepts) terminent le volume. 